\title{
Entrepreneurship and Heterogeneous Capital
}

\author{
Foss, Nicolai Juul; Klein, Peter G.
}

Document Version

Final published version

Publication date:

2008

\section{License \\ CC BY-NC-ND}

Citation for published version (APA):

Foss, N. J., \& Klein, P. G. (2008). Entrepreneurship and Heterogeneous Capital. Center for Strategic Management and Globalization. SMG Working Paper No. 3/2008

Link to publication in CBS Research Portal

\section{General rights}

Copyright and moral rights for the publications made accessible in the public portal are retained by the authors and/or other copyright owners and it is a condition of accessing publications that users recognise and abide by the legal requirements associated with these rights.

\section{Take down policy}

If you believe that this document breaches copyright please contact us (research.lib@cbs.dk) providing details, and we will remove access to the work immediately and investigate your claim. 


\section{ENTREPRENEURSHIP AND HETEROGENEOUS CAPITAL}

Nicolai J. Foss

Peter G. klein

SMG WP 3/2008

January 30, 2008 
SMG Working Paper No. 3/2008

January 30, 2008

ISBN: 978-87-91815-16-4

Center for Strategic Management and Globalization Copenhagen Business School

Porcelænshaven 24

2000 Frederiksberg

Denmark

www.cbs.dk/smg 


\title{
ENTREPRENEURSHIP AND HETEROGENEOUS CAPITAL
}

\author{
Nicolai J. Foss \\ Center for Strategic Management and Globalization \\ Copenhagen Business School \\ Porcelainshaven 24 \\ 2000 Frederiksberg, Denmark \\ njf.smg@cbs.dk \\ Peter G. Klein \\ Contracting and Organizations Research Institute \\ University of Missouri \\ 135 Mumford Hall \\ Columbia, MO 65211 USA \\ kleinp@missouri.edu \\ January 30, 2008; word count (main body): 7,503
}

\section{ACKNOWLEDGMENTS}

The paper is a draft of Chapter 4 of Foss and Klein, Organizing Entrepreneurship: Judgment and the Theory of the Firm. Cambridge: Cambridge University Press.

KEYWORDS: Austrian capital theory, entrepreneurship, heterogeneity, attributes. 


\title{
ENTREPRENEURSHIP AND HETEROGENEOUS CAPITAL
}

\begin{abstract}
Entrepreneurship is ultimately about the arrangement of resources into productive activities. Much of the entrepreneurship literature, however, has focused on the demand side of the market. While resource heterogeneity is a feature of many theories of the firm, such theories are not built on a systematic theory of capital. We show how the approach to capital developed by the Austrian school of economics provides a natural bridge between theory of entrepreneurship and the theory of the firm. We refine Austrian capital theory by defining capital heterogeneity in terms of subjectively perceived attributes, the functions, characteristics, and uses of capital assets. Such attributes are not given, but have to be created or discovered by means of entrepreneurial action.
\end{abstract}




\section{INTRODUCTION}

Entrepreneurship is ultimately about the arrangement of resources into productive activities. Much of the entrepreneurship literature, however, has focused on the demand side of the market. Entrepreneurs, that is, are concerned mainly with identifying opportunities for bringing new products and services to market; once those opportunities are recognized, the production process itself is relatively straightforward. However, if productive resources are heterogeneous, their attributes not fully known, and their interactions with complementary resources uncertain, then the exact means by which entrepreneurial opportunities are exploited becomes a central focus of entrepreneurship theory. ${ }^{1}$

Resource heterogeneity is of course a main feature of many theories of the firm. Transaction cost, property rights, and resource-based approaches to the firm assume that assets, both tangible and intangible, are to various degrees unique or specialized to particular activities. Arranging these assets to minimize contractual hazards, to provide efficient investment incentives, or to exploit competitive advantage is conceived as the prime task of economic organization. None of these approaches, however, is based on a systematic theory of capital heterogeneity.

We show here how the approach to capital developed by the Austrian school of economics provides a natural bridge between theory of entrepreneurship and the theory of the firm. The Austrian school of economics (Menger, 1871; Böhm-Bawerk, 1889; Mises, 1949; Lachmann, 1956; Rothbard, 1962; Hayek, 1948, 1968; Kirzner, 1973) has become a relatively influential source theory in various parts of management research, particularly strategic management (Jacobson 1992; Hill and Deeds, 1996; Roberts and Eisenhardt, 2003 Chiles and Choi, 2000; Lan-

\footnotetext{
${ }^{1}$ Chandler makes a similar point in his Scale and Scope (1990); namely, that the growth of American capitalism in the late 19th and early 20th centuries was due not simply to increased investment and technical change - as entrepreneurial responses to the opportunities presented by the emergence of new markets - but by the creation of new management structures that made large-scale production feasible.
} 
glois, 2001; Chiles, 2003) and entrepreneurship research (Shane, 2003). It is particularly wellknown for its contributions to the theory of entrepreneurship and the complementary "market process" account of economic activity), while other characteristically Austrian ideas such as the time structure of capital and the "malinvestment" theory of the business-cycle theory have received much less attention.

We refine Austrian capital theory by defining capital heterogeneity in terms of subjectively perceived attributes, the functions, characteristics, and uses of capital assets. Such attributes are not given, but have to be created or discovered by means of entrepreneurial action. In our view, capital assets are heterogeneous to the extent that they possess various attributes, many of which may be unknown to the owners of these assets. Moreover, many attributes are costly to measure. This links capital theory to issues of ownership and property rights (Barzel, 1997). Because entrepreneurs typically lack perfect knowledge of an asset's relevant attributes, it is usually the assets themselves, and not particular attributes, which are traded in capital markets (Foss and Foss, 2001). Ownership of an asset confers the (residual) right to exploit future, as yet undiscovered, attributes of that asset, and entrepreneurs may acquire assets precisely to be in a position to exploit these future attributes.

Indeed, several Austrians, have linked entrepreneurship to the theory of capital. As Lachmann $(1956: 13,16)$ argued: "We are living in a world of unexpected change; hence capital combinations ... will be ever changing, will be dissolved and reformed. In this activity, we find the real function of the entrepreneur." It is this "real function" that we elaborate in the following.

\section{CAPITAL, ENTREPRENEURSHIP, AND THE THEORY OF THE FIRM}

\section{Shmoo Capital and Its Implications}


Modern (neoclassical) economics focuses on a highly stylized model of the production process. The firm is a production function, a "black box" that transforms inputs (land, labor, capital) into output (consumer goods). As is widely recognized in modern treatments of the firm, this model omits the critical organizational details of production, rarely looking inside the black box to see how hierarchies are structured, how incentives are provided, how teams are organized, and the like.

An equally serious omission, perhaps, is that production is treated as a one-stage process, in which factors are instantly converted into final goods, rather than a complex, multi-stage process unfolding through time and employing rounds of intermediate goods. "Capital" is treated as a homogeneous factor of production, the " $K$ " that appears in the production function along with "L" for labor. Following Solow (1957) models of economic growth typically model capital as what Paul Samuelson called "shmoo"- an infinitely elastic, fully moldable factor that can be substituted costlessly from one production process to another.

In a world of shmoo capital economic organization is relatively unimportant. All capital assets possess the same attributes, and thus the costs of inspecting, measuring, and monitoring the attributes of productive assets is trivial. Exchange markets for capital assets would be virtually devoid of transaction costs. A few basic contractual problems - in particular, principal-agent conflicts over the supply of labor services - may remain, though workers would all use identical capital assets, and this would greatly contribute to reducing the costs of measuring their productivity. While transaction costs would not disappear entirely in such a world, asset ownership would be relatively unimportant. The possibility of specifying all possible uses of an asset significantly reduces the costs of writing complete, contingent contracts between resource owners 
and entrepreneurs governing the uses of the relevant assets. ${ }^{2}$ Contracts would largely substitute for ownership, leaving the boundary of the firm indeterminate (Hart, 1995).

Note also that in the world of shmoo capital, the coordination problem becomes a simple one (Hayek, 1941; Lachmann, 1956; Garrison, 2000). Since all capital assets are homogenous (including human capital), coordination concerns selecting the "doses" of input services that must be applied over time. However, the intertemporal coordination problem is also very simple, as presumably there is no path-dependence in a world in which capital is genuinely homogenous: Sources of path-dependence such as complementarity between capital assets disappear (all assets are substitutes). Thus, in a world of shmoo, coordination of plans is relatively straightforward. In the real world of heterogeneous capital assets, production plans are much more difficult to coordinate. Neoclassical microtheory sidesteps these problems by focusing on production functions, which assume that the assets controlled by the firm are already in their best uses.

However, it is hard to define a role for entrepreneurship in such a world, at least to the extent that entrepreneurship is understood as having a forward-looking, speculative component in which the bearing of risk is important. The scope of entrepreneurial activity would also be severely reduced, since entrepreneurs would have no need to arrange particular combinations of capital assets to serve current and future needs. If capital were a single "good" with one price, we would only have to choose between capital-intensive and labor-intensive production methods (or among types of labor). Few "calculation problems" (Mises, 1949) would exist in such a world. Moreover, as Foss et al. (2007) argue, in a world of homogenous capital goods (resources), decision problems would be trivialized as all capital goods possess the same attributes,

\footnotetext{
${ }^{2}$ Contracts might still be incomplete because contracting parties have different, subjective expectations about the likelihood of various contingencies affecting the value of the (homogeneous) capital asset. Agents may also differ in their ability to learn about possible uses of the capital good. In other words, Knightian uncertainty plus bounded rationality could drive contractual incompleteness even in a world without capital heterogeneity. However, the neoclassical world of shmoo capital is characterized by parametric uncertainty, common priors, and hyperrationality.
} 
and thus the costs of inspecting, measuring, and monitoring the attributes of productive assets would be trivial (Barzel, 1997). Finally, a world of homogenous capital is a non-complex world, one in which decision-makers do not reach the bounds of their rationality (Simon, 1955).

\section{Heterogeneous Capital in the Theory of the Firm}

By contrast, all modern theories of the firm assume (often implicitly) that capital assets possess varying attributes, so that all assets are not equally valuable in all uses. Notably, in transaction cost economics (Williamson, 1975, 1985, 1996) and the "new" property-rights approach (Grossman and Hart, 1986; Hart and Moore, 1990), some assets are conceived as specific to particular users. If complete, contingent contracts specifying the most valuable uses of such assets in all possible states of the world cannot be written, then owners of productive assets face certain risks. Primarily, if circumstances change unexpectedly, the original governing agreement may no longer be effective. The need to adapt to unforeseen contingencies constitutes an important cost of contracting. Failure to adapt imposes what Williamson (1991) calls "maladaptation costs," the best known of which is the "holdup" problem associated with relationship-specific investments. It is obvious that maladaptation costs largely disappear if all assets are equally valuable in all uses (the economic meaning of capital homogeneity). Potential holdup would still be a concern for owners of relationship-specific human capital (if we exclude this from the category of capital goods) and raw materials, but disagreements over the efficient use of capital goods would become irrelevant. ${ }^{3}$

Management scholars will hardly be startled by the claim that entrepreneurs organize, deploy and adjust heterogeneous capital goods. The management literature abounds with notions of heterogeneous "resources," "competencies," "capabilities," "assets," and the like. And, indeed, Re-

\footnotetext{
${ }^{3}$ Resources that are initially homogenous could become heterogeneous over time, through learning by doing or cospecialization of human and physical capital. Here we refer to conditions of permanent homogeneity.
} 
source-based (Wernerfelt, 1984; Barney, 1991; Lippman and Rumelt, 2003) and knowledgebased (Penrose, 1959; Grant, 1996) approaches emphasize capital heterogeneity, but their focus is not generally economic organization, but rather competitive advantage. ${ }^{4}$ The emphasis in these approaches is not economic organization, however, but competitive advantage. The latter is seen as emerging from bundles of resources (including knowledge). Different resource bundles are associated with different efficiencies, translating into a theory of competitive advantage. Resource- and knowledge-based scholars often emphasize that heterogeneous assets do not give rise independently to competitive advantages. Rather, it is the interactions among these resources, their relations of specificity and co-specialization, that generate such advantages (e.g., Dierickx and Cool, 1989; Barney, 1991; Black and Boal, 1994). However, this notion is not developed from any comprehensive perspective on asset specificity and co-specialization (or complementarity) (as in Teece 1982).

While capital heterogeneity thus plays an important role in transaction cost, resource-based, and property-rights approaches to the firm, none of these approaches rests on a unified, systematic theory of capital. Instead, each invokes the needed specificities in an ad hoc fashion to rationalize particular trading problems - for transaction cost economics, asset specificity; for capabilities theories, tacit knowledge; and so on. ${ }^{5}$ The Austrian school offers a systematic, comprehensive theory of capital, and Austrian notions of capital heterogeneity can inform, synthesize, and improve the treatment of specificities in the theory of the firm. Adopting the Austrian view

\footnotetext{
${ }^{4}$ Penrose's approach, unlike modern resource- and knowledge-based approaches, did emphasize one important element of economic organization, namely the rate of growth of the firm.

${ }^{5}$ Some writers (Winter, 1988; Demsetz, 1991; Langlois and Foss, 1999) argue that the economics of organization has shown a tendency (albeit an imperfect one) to respect an implict dichotomy between production and exchange. Thus, as Langlois and Foss (1999) argue, there is an implicit agreement that the production function approach with its attendant assumptions (e.g., blueprint knowledge) tells us what we need to know about production, so theories of the firm can focus on transacting and how transactional hazards can be mitigated by organization. Production issues, including capital theory, never really take center stage. This is problematic if production itself reveals new problems of transacting that may influence economic organization.
} 
of capital also reveals new sources of transaction costs that influence economic organization. Moreover, as argued, the world of heterogeneous capital assets - the world of Austrian capital theory - is a world where there is something for the entrepreneur to do. In other words, capital theory bridges our thinking about the entrepreneur with our thinking on economic organization.

\section{AUSTRIAN CAPITAL THEORY: AN OVERVIEW}

The concept of heterogeneous capital has a long and distinguished place in Austrian economics. ${ }^{6}$ The development of Austrian capital theory has been marked by the struggle to develop consistent analytical categories and aggregate measures for a class of goods that are fundamentally heterogeneous. In general, Austrian writers have moved away from relatively aggregate concepts emphasized by Böhm-Bawerk (1959) towards increasingly disaggregated ones that are more consistent with Austrian methodological individualism and subjectivism Evin, 2000).

Early Austrian writers recognized that capital has a time dimension as well as a value dimension. Menger (1871) characterized goods in terms of "orders": Goods of lowest order are those consumed directly; tools and machines used to produce those consumption goods are of a higher order; and those capital goods used to produce the tools and machines are of an even higher order. $^{7}$ Building on his theory that the value of all goods is determined by their ability to satisfy consumer wants, Menger showed that the value of the higher-order goods is given ("imputed") by the value of the lower-order goods they produce. Moreover, because certain capital goods are themselves produced by other, higher-order capital goods, it follows that capital goods are not identical, at least by the time they are employed in the production process. This is not to say that there is no substitution among capital goods, but that the degree of substitution is limited; as

\footnotetext{
${ }^{6}$ For overviews see Strigl (1934), Kirzner (1966), and Lewin (1999).

${ }^{7}$ Böhm-Bawerk (1959) used the term "maturity classes" for the same concept.
} 
Lachmann (1956) put it, capital goods are characterized by "multiple specificity." Some substitution is possible, but only at a cost.

Hayek's Prices and Production (1931) introduced the famous "Hayekian triangles" to illustrate the relationship between the value of capital goods and their place in the temporal sequence of production. Because production takes time, factors of production must be committed in the present for making final goods that will have value only in the future after they are sold. However, capital is heterogeneous. As capital goods are used in production, they are transformed from general-purpose materials and components to intermediate products specific to particular final goods. Consequently, these assets cannot be easily redeployed to alternative uses if demands for final goods change. The central macroeconomic problem in a modern capital-using economy is thus one of intertemporal coordination: how can the allocation of resources between capital and consumer goods be aligned with consumers' preferences between present and future consumption? In The Pure Theory of Capital (1941) Hayek describes how the economy's structure of production depends on the characteristics of capital goods-durability, complementarity, substitutability, specificity, and so on. This structure can be described by the various "investment periods" of inputs, an extension of Böhm-Bawerk's notion of "roundaboutness," the degree to which production uses resources over time. ${ }^{8}$

This understanding of capital as a complex structure formed the basis of the Mises-Hayek theory of the business cycle. Monetary injections, by lowering the rate of interest below its "natural rate," distort the economy's intertemporal structure of production. The reduction in interest rates caused by credit expansion directs resources toward capital-intensive processes and early stages of production (whose investment demands are more interest-rate elastic), thus

\footnotetext{
${ }^{8}$ Hayek ultimately rejected Böhm-Bawerk's "average period of production" as a useful concept, though he had used it earlier in Prices and Production (1931) (see Hayek 1941).
} 
"lengthening" the period of production. Investments in some stages of production are "malinvestments" if they do not help to align the structure of production to consumers' intertemporal preferences. The boom generated by the increase in investment is artificial; eventually, market participants come to realize that there are not enough savings to complete all the new projects, and the boom becomes a bust as these malinvestments are discovered and liquidated.

The concept of "malinvestment" is foreign to neoclassical production theory (as well as mainstream macroeconomics), which usually considers only the level of investment. Modern production theory focuses on a single stage of production in which "capital," along with other inputs, is transformed into final goods. In economics textbooks, the "firm" is a production function or production possibilities set, a "black box" that transforms inputs into outputs. Given the existing state of technology, the prices of inputs, and a demand schedule, the firm maximizes money profits subject to the constraint that its production plans must be technologically feasible. The legal boundary of the firm - defined in terms of the ownership of assets - is indeterminate in these models.

Inspired by Hayek (1941), Lachmann (1956) developed a fundamentally subjectivist conception of "capital structure", the two key concepts of which are capital heterogeneity and capital complementarity. "In the sphere of human action, Structure implies Function, and Function, where a number of factors is involved, implies co-ordination and complementarity" (p.114). Every specific piece of capital equipment is designed for a certain purpose, so that capital heterogeneity emerges from "[p]roducts of the human mind, artifacts, produced in accordance with a plan" (p.112). In a capital structure, each capital good has a definite function and the various goods are, too varying degrees, complements (see also Lachmann, 1986: Chapter 4). Indeed, it seems that in reality individual capital goods should be expected to be substitutable for some other use. For example, each locomotive is a complement to a number of wagons but is also, at 
the same time, to a greater or lesser extent, a substitute for any other locomotive (Lachmann, 1947: 109). However, if this is so, the next question, Lachmann points out, is to ask "whether complementarity or substitutability is the dominant relationship, or more precisely, under what conditions we expect one or the other to predominate" (p.109). Lachmann (1947: 110) continues:

Factor complementarity and substitutability are phenomena belonging to different provinces of the realm of action. Complementarity is a property of means employed for the same end, or a group of consistent ends. All the means jointly employed for the same end, or such ends, are necessarily complements. Factor complementarity presupposes a plan within the framework of which each factor has a function.

In other words, when we say that a certain capital good that is functionally connected with a preceding production plan may be substitutable for other forms of production or usage, we must presuppose an alternative plan for its usability. Toward this new end, the capital good must be a complement, not a substitute. In fact, Lachmann argues, substitutability is a "phenomenon of change" that arises whenever an initial plan has gone wrong (p.110). That is, substitutability becomes meaningful only after a factor can no longer be part of an existing plan. In this respect, complementarity is a feature of stability, implying a certain technical rigidity (Lewin, 2005: 14). The capital goods that lose their function in an initial plan have to be scrapped or, at best, regrouped within another plan (what Lachmann [1956:2] calls “multiple specificity"). ${ }^{9}$

Thus, it is clear that Lachmann's capital theoretic outlook is firmly embedded in a process view of economic activity. Consistent with this, Lachmann (1986: 65) took issue with the Marshallian notion that the "short run" may be defined as the capital stock being given: "... short-run

\footnotetext{
${ }^{9}$ One implication is that the view that capital complementarity and substitutability are alternative modes of the relationship between capital goods in the same situation rests on a fallacy (Lachmann 1947: 110).
} 
change in the pattern of use of existing capital goods in the form of a reshuffling of capital combinations is ubiquitous." Contrast this with the RBV core model, which is essentially a model of firms with given endowments of resources, earning differential rents on these in equilibrium, an equilibrium which is defined by all attempts at imitating a successful firm's strategy having ceased (so that no "reshuffling of capital combinations" goes on). Such an equilibrium has no place in the Lachmannian scheme.

Lachmann further points out that many productive activities are not automatically coordinated by an anonymous price system and that the role of specifying, modifying, and making decisions on the concrete form that the capital resource is potentially to have is the significant function of the entrepreneur (1976: 16). ${ }^{10}$ Therefore, the form of capital as structure is derived from entrepreneurial plans.

Kirzner (1966) provided an important refinement to the Austrian theory of capital by emphasizing the role of the entrepreneur (the theme that dominates Kirzner's later work). ${ }^{11}$ Earlier Austrian writers, particularly Böhm-Bawerk, tried to characterize the economy's capital structure in terms of its physical attributes. Böhm-Bawerk attempted to describe the temporal "length" of the structure of production by a single number, the "average period of production." This attempt Böhm-Bawerk was sharply criticized by John Bates Clark (1893) and by Menger himself (who called Böhm-Bawerk's capital theory "one of the greatest errors ever committed" (Schumpeter 1954: 847n8)). Kirzner's approach avoids these difficulties by defining capital assets in terms of subjective, individual production plans, plans that are formulated and continually revised by profit-seeking entrepreneurs. Capital goods should thus be characterized, not by their physical

\footnotetext{
${ }^{10}$ Lachmann distinguishes the role of the entrepreneur from the function of the manager. He says the revision of plans is the function of the entrepreneur and the carrying out of existing plans is the function of the manager (See the footnote.1, p.113). In our discussion, we follow his distinction although the definition of entrepreneurship may be otherwise in practice (Gartner, 1990).

${ }^{11}$ See also the essays collected in Kirzner (1996).
} 
properties, but by their place in the structure of production as conceived by entrepreneurs. The actual place of any capital good in the time sequence of production is given by the market for capital goods, in which entrepreneurs bid for factors of production in anticipation of future consumer demands. This subjectivist, entrepreneurial approach to capital assets is particularly congenial to theories of the firm that focus on entrepreneurship and the ownership of assets.

In the following we extend Austrian capital theory in two directions. First, we provide an interpretation of "heterogeneity" and link the theory to ideas on property rights and transaction costs. This links Austrian capital theory and economic organization. Second, we explore entrepreneurial action in a world of heterogeneous capital, drawing on ideas on problem-solving. This links Austrian capital theory and entrepreneurship.

\section{CAPITAL HETEROGENEITY, ATTRIBUTES, AND OWNERSHIP}

The Austrian approach to capital generated considerable controversy, both within the school itself and between the Austrians and rival schools of economic thought. Given the attention devoted to the problem of measuring a heterogeneous capital stock, it is surprising that relatively little analytical effort has been devoted to the concept of heterogeneity itself. The notion of heterogeneous capital is crucial not just for Austrian capital theory, but for (Austrian) economics in general. For example, the Austrian position in the socialist calculation debate of the 1930s (Mises, 1920; Hayek, 1935) is based on an entrepreneurial concept of the market process, one in which the entrepreneur's primary function is to choose among the various combinations of factors suitable for producing particular goods (and to decide whether these goods should be produced at all), based on current prices for the factors and expected future prices of the final goods. If capital is shmoo with one price, then entrepreneurship is reduced to choosing between shmoointensive and labor-intensive production methods (or among types of labor), a problem a central 
planner could potentially solve. The failure of socialism, in Mises's (1920) formulation, follows precisely from the complexity of the economy's capital structure, and the subsequent need for entrepreneurial judgment. Kirzner's argument that capital goods are heterogeneous not because of their objective characteristics, but because they play particular roles within the entrepreneur's overall production plan, further developed the link between entrepreneurship and capital heterogeneity.

\section{Heterogeneity as Attribute Variance}

A sophisticated approach to capital heterogeneity can be drawn from the property-rights approach associated with economists such as Coase (1960), Alchian (1965), Demsetz (1964, 1967), and, particularly, Barzel (1997). These writers focus not on individual assets per se, but on bundles of asset attributes to which property rights may be held (Foss and Foss 2001).

While it is common to view capital heterogeneity in terms of physical heterogeneity—beer barrels and blast furnaces are different because of their physical differences- - the old propertyrights approach emphasizes that capital goods are heterogeneous because they have different levels and kinds of valued attributes (in the terminology of Barzel, 1997). ${ }^{12}$ Attributes are characteristics, functions, or possible uses of assets, as perceived by an entrepreneur. For example, a copying machine has multiple attributes because it can be used at different times, by different people, and for different types of copying work; that it can be purchased in different colors and sizes; and so on. ${ }^{13}$ Rights to such attributes can be defined and traded, depending on transaction costs (Foss and Foss, 2001).

\footnotetext{
${ }^{12}$ Foss and Foss (2005) link the property rights approach to the resource-based view, demonstrating how the more "micro" approach of the property rights approach provides additional insights into resource value. See also Kim and Mahoney $(2002,2005)$ for similar arguments.

${ }^{13}$ Clearly, this notion of subjectively perceived attributes of capital assets is related to Penrose's (1959) point that the physically capital assets may yield different services, depending on, for example, the nature of the administrative
} 
Clearly, virtually all assets have multiple attributes. Assets are heterogeneous to the extent that they have different, and different levels of, valued attributes. Physically identical assets may still be heterogeneous in an economic sense, because their holders may hold different conceptions of their attributes. As Alchian and Demsetz (1972: 793) note, “[e]fficient production with heterogeneous resources is a result not of having better resources but in knowing more accurately the relative productive performances of those resources." Contra the production function view in basic neoclassical economics, such knowledge is not given, but has to be created or discovered.

Attributes may also vary over time, even for a particular asset. In a world of "true" uncertainty, entrepreneurs are unlikely to know all relevant attributes of all assets when production decisions are made. Nor can the future attributes of an asset, as it is used in production, be forecast with certainty. Future attributes must be discovered, over time, as assets are used in production. Or, to formulate the problem slightly differently, future attributes are created as entrepreneurs envision new ways of using assets to produce goods and services. ${ }^{14}$

\section{Heterogeneity and Ownership}

Focusing on attributes not only helps conceptualize heterogeneous capital, but also illuminates the vast literature on transaction costs, property rights and ownership. Barzel (1997) stresses that property rights are held over attributes; in his work, property rights to known attributes of assets are the relevant units of analysis. In contrast, he dismisses the notion of asset ownership as essentially legal and extra-economic. Similarly, Demsetz argues that the notion of "full private ownership" over assets is "vague," and "must always remain so," because "there is an

\footnotetext{
framework in which they are embedded.

${ }^{14}$ In this paper we do not distinguish between "discovery" and "creation" as alternative conceptions of the entrepreneurial act, though we recognize the general importance of the distinction (Alvarez and Barney, 2005).
} 
infinity of potential rights of actions that can be owned.... It is impossible to describe the complete set of rights that are potentially ownable" (Demsetz, 1988:19).

However, as we noted above, most assets have unspecified, unknown future attributes, and an important function of entrepreneurship is to create or discover these attributes. Contrary to Demsetz, it is exactly this feature that creates a distinct role for asset ownership, the acquisition of legal title to a bundle of existing and future attributes. Specifically, ownership is a low-cost means of allocating the rights to attributes of assets that are created or discovered by the entrepreneur-owner. For instance, those who create or discover new knowledge have an incentive to use it directly because it is costly to transfer knowledge to others. In a well-functioning legal system, ownership of an asset normally implies that the courts will not interfere when an entrepreneur-owner captures the value of newly created or discovered attributes of an asset he owns. Consequently, the entrepreneur-owner can usually avoid costly negotiation with those who are affected by his creation or discovery. Moreover, asset ownership itself provides a powerful incentive to create or discover new attributes, as ownership conveys the legally recognized (and at least partly enforced) right to the income of an asset, including the right to income from new attributes.

\section{Heterogeneous Capital and Experimental Entrepreneurship}

The Austrian idea of heterogeneous capital is thus a natural complement to the theory of entrepreneurship. ${ }^{15}$ Entrepreneurs who seek to create or discover new attributes of capital assets will want ownership titles to the relevant assets, both for speculative reasons and for reasons of economizing on transaction costs. These arguments provide room for entrepreneurship that goes

\footnotetext{
${ }^{15}$ We note in passing that the understanding of management may also be furthered by beginning from heterogeneous capital assets and the need for coordination they imply. From a resource-based view, Mahoney (1995) argues that an important function of management is the coordination of such assets.
} 
beyond deploying a superior combination of capital assets with "given" attributes, acquiring the relevant assets, and deploying these to producing for a market: Entrepreneurship may also be a matter of experimenting with capital assets in an attempt to discover new valued attributes.

Such experimental activity may take place in the context of trying out new combinations through the acquisition of or merger with another firms, or in the form of trying out new combinations of assets already under the control of the entrepreneur. The entrepreneur's success in experimenting with assets in this manner depends not only on his ability to anticipate future prices and market conditions, but also on internal and external transaction costs, the entrepreneur's control over the relevant assets, how much of the expected return from experimental activity he can hope to appropriate, and so on. Moreover, these latter factors are key determinants of economic organization in modern theories of the firm, which suggests that there may be fruitful complementarities between the theory of economic organization and Austrian theories of capital heterogeneity and entrepreneurship.

\section{CAPITAL AND ENTREPRENEURIAL JUDGMENT}

\section{Capital as a Complex Structure}

As Peter Lewin (2005) rightly points out, one of the main contributions of post-Bohm Bawerkian Austrian capital theory is the emphasis on the structure dimensions of the capital stock rather than on the aggregate value dimension or notions such as roundaboutness. Indeed, echoing Lachmann, Lewin makes the case that the doctrinal history of economics demonstrates two very different approaches to capital theory, one structuralist (associated with Smith, Menger, the Hayek of the Pure Theory of Capital and Lachmann) and one quantitative (associated with Ricardo, Böhm-Bawerk and Solowian growth theory). In the latter approach, capital goods are not necessarily assumed to be homogenous, but there is a claim that they can be made commensura- 
ble in value terms, aggregated together, and that this aggregate result has economic significance. There is no particular emphasis on the relations between capital goods. In long-run equilibrium or full intertemporal equilibrium $\equiv$ a Debreu 1959) the structuralist and the quantitative approaches become identical in their economic implications.

As Lewin (2005) clarifies, a structure of capital goods becomes a structure rather than just a list of heterogeneous capital goods because it is possible to say something about the overall structure from inspection of a few (possibly typical) capital goods and knowledge of principles of composition. This indicates that a capital structure may have systemic properties. We argue here that a natural complement to structural Austrian capital theory is the theory of complex systems associated with Simon (1962) and Kauffman (1993) (for various social science applications, see Levinthal, 1997; Fleming, 2001; Langlois, 2003; Nickerson and Zenger, 2004).

Simon (1962) defines "complexity" as obtaining when a large number of parts "interact in a nonsimple way" (1962: 468). Such complexity frequently takes the form of a hierarchy, that is, as a system that is composed of interrelated (complementary) subsystems. Each one of these subsystems are, in turn, hierarchical in nature, until some elementary subsystem is reached at the lowest level. "In hierarchic systems," Simon explains, “... we can distinguish between the interactions among subsystems on the one hand, and the interactions within subsystems - i.e., among the parts of those subsystems — on the other" (1962: 473). This forms the basis for the often cited distinction between decomposable systems, in which the interactions among the subsystems are negligible; non-decomposable systems, in which the interactions among the subsystems are essential; and nearly decomposable systems, in which the interactions among the subsystems are weak, but not negligible (1962: 129). ${ }^{16}$

\footnotetext{
${ }^{16}$ For an application to the theory of the firm with broadly Austrian features, see Langlois (2002).
} 
The relevance of these distinctions to Austrian capital theory is indicated by, for example, the reinterpretation of the Bohm-Bawerkian concept of roundaboutness in such works as Hayek (1941) and Lachmann (1956) where increasing roundaboutness is interpreted as an increasing number of capital goods with more complex interactions (typically an increasing number of relations of complementarity and specificity). Thus, increasing roundaboutness implies that the overall capital structure becomes less "decomposable" in Simon's terms.

\section{A Problem-Solving Perspective}

Simon's (1962) main aim is to explain an important aspect of the ontology of the social and natural world. However, there is also an epistemological dimension to his discussion. Thus, he points out that an important aspect of what makes the social and natural world comprehensible is that they often involve phenomena that may be represented as nearly decomposable hierarchies; for example, "[s]ubparts belonging to different parts only interact in an aggregative fashion - the detail of their interaction can be ignored" (1962: 477). We can understand the system exactly because we can ignore these "details"; if we also had to comprehend the details it would be "beyond our capacities of memory and computation" (ibid.) to understand the full system. In other words, the epistemological problem of comprehending a complex system is eased when the system is decomposable or nearly decomposable.

One implication, which is often noted, is that problem-solving may proceed by means of decomposing problems into sub-problems (Loasby, 1976). Another implication is that systems, such as capital structures, that are close to the non-decomposable end of the spectrum may be hard to comprehend. In terms of later complexity research (e.g., Kauffman, 1993), the "landscape" of combinations of elements may have multiple peaks. More generally, a landscape is a mapping of how combinations of certain entities perform in terms of some metric. For example, 
theoretical biologists construct fitness landscapes that map gene combinations into fitness values. One may in an analogous manner think of a landscape of combinations of capital goods that are mapped into (appropriable) monetary values. Finding the optimal (highest) peak in such a landscape may be far from trivial. In general, work on search operations in complex systems (Levinthal, 1997; Fleming, 2001) demonstrates how the overall performance of the search effort is highly dependent on the characteristics of the system: whether they are decomposable, nondecomposable or nearly decomposable, for example. In particular, search operations in systems that lie close to the non-decomposable end of the spectrum are a tough undertaking, particularly when the search methods are primitive (e.g., gradient search), because in such systems the landscape of combinations of elements will have multiple peaks (in extreme cases, this may produce a "complexity catastrophe", Kauffman, 1993). ${ }^{17}$ This is consistent with the finding that firms often find it difficult to comprehend "architectural" knowledge, that is, knowledge of the multiple links between product components (Henderson and Clark, 1990). On the other hand, in strongly decomposed systems, the landscape may be single-peaked, so that even simple learning modes may quickly reach the peak.

Another related point is the notion that complex relations of complementarity between multiple resources/capital goods may be an important independent barrier to competitive imitation, even if all of the individual resources are perfectly imitable (Rivkin, 2000). A third implication is that there is a distinction between the interdependencies between elements/capital goods in a system/structure that are given to an omniscient observer and those interdependencies that can be seen or imagined by an agent such as a real-world entrepreneur. We elaborate the latter implication in the following.

\footnotetext{
${ }^{17}$ The height of peaks may here be taken as a measure of the profitability implications of a given combination of capital goods.
} 


\section{Search and Entrepreneurial Judgment}

The above ideas would be irrelevant in a full intertemporal equilibrium setting $\equiv \mathrm{E}$ ek, 1928; Debreu 1959). In such a world, all possible combinations of capital goods would be priced, and all prices would perfectly reflect scarcities. Imputation would be perfect. Under these circumstances, there would be no need for entrepreneurs who, based on their speculative appraisals, could test alternative combinations of capital goods in the market place (Mises, 1949; Salerno, 1999). As all prices would equal NPVs (because of the combined assumptions of perfect foresight and competitive conditions), there would be no profits in this world. While all "entrepreneurial" strategies (in the sense of possibilities of action) would be recognized and fully priced, any viable strategy would be as good (or bad) as any other (i.e., earning zero profits) (Denrell, Fang and Winter, 2003). There would be no need for any search in the landscape of combinations of capital goods, as the highest peaks would be immediately visible to entrepreneurs. This is what Lippman and Rumelt (2003: 1982) call "full strategic equilibrium" which maximizes surplus across the set of all possible assignments of all possible resources to all possible tasks. ${ }^{18}$

However, with a very different social ontology, one characterized by dispersed knowledge (Hayek, 1948), genuine uncertainty (Knight, 1921; Mises, 1949), bounded rationality (Simon, 1955), and sheer ignorance (Kirzner, 1973) - the ontology adopted in this work - current prices cannot reflect all combinations of complementary capital goods, that is, all their "multiple specificities." Instead, intertemporal resource allocation is taken care of by entrepreneurs:

We are living in a world of unexpected change; hence capital combinations, and with them the capital structure, will be ever changing, will be dissolved and re-

\footnotetext{
${ }^{18}$ They note in passing that "[t]he number of such combinations, in the real world, is literally noncomputable. The idea that firms actually operate at the maximum within this space is not credible" (ibid.).
} 
formed. In this activity we find the real function of the entrepreneur (Lachmann, 1956: 13).

How does entrepreneurial activity proceed? The best known treatments of entrepreneurship, those of Schumpeter (1934), Knight (1921) and Kirzner (1973), identify entrepreneurship with the commercialization of "new combinations," the exercise of judgment, and alertness, respectively. In these treatments there is, in actuality, rather little on the actual process of setting up the new means-ends framework (Harper, 1996). Entrepreneurial searching is somewhat played down. In fact, Kirzner appears to be at pains to dissociate himself from notions of search which he sees as wedded to to "Robbinsian maximization" (i.e., search implies an opportunity cost which can be economized). However, while serendipity, luck, and Kirznerian alertness surely play a role in entrepreneurial activity, so does active search (Casson, 1982; Shane, 2003). The theory of complex systems may add to the understanding of entrepreneurial search.

In terms of this perspective, we can think of the multiple possible combinations of capital goods as defining a landscape. If capital was Solowian shmoo, the landscape would be entirely flat as any combination of shmoo would be as good as any other combination. However, with capital heterogeneity, peaks emerge. As the capital structure becomes increasingly complex, the landscape becomes increasingly multi-peaked. Of course, with full information and perfect foresight, all entrepreneurs would enjoy a clear view of the "objectively" existing fitness landscape. In actuality, however, entrepreneurs have only an imperfect model or theory (Choi, 1993; Harper, 1995) of the profitability implications of alternative combinations of capital goods.

As Lachmann (1956: 3) notes, “[t]he 'best' mode of complementarity is ... not a 'datum'. It is in no way 'given' to the entrepreneur who, on the contrary, as a rule has to spend a good deal of time and effort in finding out what it is." Thus, the entrepreneur undertakes search. Search 
efforts may or may not give rise to the discovery of valuable capital combinations. In the literature on complex systems, search outcomes (such as valuable capital combinations) are usually said to depend on the mode of search (Levinthal, 1997) — for example, whether search takes place through incremental, trial-and-error search ("gradient search") or whether it takes place based on explicit theories of cause-effect ("heuristic search") — and, as already indicated, on the nature of the landscape over which search takes place.

A potential Austrian critique of much of the complexity literature is that it often "dumbs down" human agents, for example, by portraying them as engaging in trial and error search with virtually no foresight. This is arguably quite true, but a broader conclusion from the literature is that, as a general rule, search modes should be matched to the characteristics of the landscape of combinations of knowledge elements in a discriminating manner. As indicated already, simple search modes will usually not suffice to discover the most valuable combinations of knowledge elements in multi-peaked landscapes. A "simple search mode" may be defined as one that makes no apriori assumptions about which knowledge elements are in the search space, how they may be connected, and the implications in terms of appropriable value. In this mode, search begins at an essentially arbitrary place and proceeds by means of trial and error. Search and learning becomes increasingly sophisticated as decision makers make explicit assumptions about which elements are relevant and how elements connect. It is arguably these latter kinds of search modes that are most closely allied to Austrian and Knightian notions of entrepreneurship, particularly because these notions already assume substantial complexity in the form of a multiplicity of combinations of capital goods and uncertainty.

The search mode that entrepreneurs will apply and the judgments they will form are determined by their theories of the complexity of the problem they face (i.e., the architecture of the landscape of capital combinations) (Choi, 1993; Harper, $\equiv \mathrm{X}$ ). This, in turn, is influenced by 
the entrepreneur's past experience. Shane (2000) argues and empirically demonstrates that entrepreneurial judgments are indeed influenced by experience because experience influences interpretation of the "facts." In a similar vein, Lachmann argues that experience is the "raw material of out of which all expectations are formed" (Lachmann, 1956:21). Since each expectation is formed as a result of a process in which a former expectation is revised through experience, the expectation that triggers entrepreneurial judgment might be different for each person implying that estimates of the NPV of a capital good/resource differ widely across agents. In this situation, some agents may acquire a resource at a price below its NPV. They may reap a rent from this resource by deploying the resource in production, or selling it. In contrast, if (a sufficient number of) agents hold the same estimate of the NPV, price will equal NPV and all rent will be absorbed in the price. By implication, expectational disequilibrium is a condition of competitive advantage, exemplifying the general importance that Lachmann ascribed to divergent expectations (Lachmann, 1977).

\section{CONCLUSION}

The point of the foregoing discussion is that a systematic account of capital heterogeneity provides a crucial bridge between theories of entrepreneurship and the firm. If capital were homogeneous, the entrepreneurial act would be straightforward: identify an unfulfilled market need, go into production, and fill it. Many, if not most, of the interesting problems of economic organization would disappear. This implies that the theory of capital should be an integral part of theories of entrepreneurship and economic organization. It also suggests extending the Austrian emphasis on entrepreneurship in markets to entrepreneurship in firms.

However, the concept of capital heterogeneity does more than simply establish the necessary conditions for entrepreneurship and the typical problems of economic organization. Taking fuller 
account of heterogeneous capital, as developed by the Austrian school, reveals exchange problems (i.e., transaction costs) that are relevant to economic organization but neglected in mainstream theories of the firm. ${ }^{19}$ In a setting with heterogeneous capital and uncertainty, the process of entrepreneurial experimentation has distinct implications for economic organization. As we shall later elaborate, the process of experimenting with heterogeneous capital may be best organized within a firm, helping to explain why firms emerge. Similarly, experiments with heterogeneous capital assets may underlie much of the observed dynamics of the boundaries of firms. Thus, it is not a priori known whether capital assets controlled by potential takeover target will be a good fit with the firm's assets; this has to be tried out in an experimental fashion. Finally, we have argued that internal organization is also illuminated by a focus on judgment, heterogeneous capital, and experimentation.

Our approach is potentially rich in explanatory power. For example, because entrepreneurial judgment requires resource ownership, the theory of employment - the contractual relations between the entrepreneurs and those they hire to help them execute their plans-is ultimately a theory of delegation. Judgment, as the ultimate decision-making factor of production (in Grossman and Hart's terminology, the residual rights of control) cannot be delegated, by definition. But many other proximate decision rights can, and frequently are, delegated to employees. Operationalizing this insight, and deriving testable implications from it, can be done by identifying the circumstances under which particular decision rights (what we may call derived judgment) can be delegated to particular individuals. These circumstances can be described by characteristics of the business environment (technology, markets, regulation), employees' human

\footnotetext{
${ }^{19}$ In contrast, our emphasis on understanding economic organization in a dynamic context has obvious parallels to Langlois's (1992) notion of "dynamic transaction costs."
} 
capital (what Schultz [1975] calls "the ability to deal with disequilibria"), and aspects of firm strategy. Consider the following applications.

Decentralization. One approach to delegation is to build on the literature on optimal decentralization, such as Jensen and Meckling's (1992) important (and, in our judgment, underappreciated) application of Hayek's and Polanyi's theory of knowledge to internal organization. Jensen and Meckling identify some benefits and costs of decentralizing decision rights to lower levels of an organization. The primary benefit is more effective use of specific (local, tacit) knowledge, while costs include potential agency problems and less effective use of central information. Decentralization, in Jensen and Meckling's terminology, achieves the co-location of knowledge and decision rights. Employees who are not owners, however, exercise only derived judgment, no matter how many decision rights they hold. Optimal decentralization can thus be interpreted in terms of the tradeoff between knowledge and judgment. Assigning decision rights to employees co-locates specific knowledge and derived judgment, while judgment itself remains in the hands of owners. The decision to decentralize therefore depends not only on the importance of specific knowledge, but on the "wedge" between ultimate and derived judgment. Where environmental uncertainty is high, this wedge may be sufficiently large that decentralization reduces firm value, even controlling for the importance of specific knowledge.

Occupational choice. Another application relates to the literature on occupational choice. Many studies of entrepreneurship treat entrepreneurship as an occupation (i.e., selfemployment), rather than a function, as we treat it here. (See, for example, Hamilton, 1990.) What is the correlation between self-employment and judgment? Self-employed individuals who finance their ventures with debt or personal savings are surely acting as Knightian entrepreneurs. If a new venture is financed with equity, then in our framework it is the financier-the venture capitalist or angel investor, for example - who is bearing the relevant uncertainty and therefore 
performing the entrepreneurial function, not the firm founder (except to the extent that the founder's compensation is a function of the outcome of the venture). We are unaware of existing empirical work relating self-employment to the entrepreneurial function, though such work should be important in understanding the role of self-employment in generating economic growth.

Contract design. Moreover, our approach to the entrepreneurial function has implications for contract design.. If we think of judgment as filling in the gaps of incomplete contracts, then the more complete the contract, the fewer circumstances in which "ultimate judgment" must be exercised, and hence the more decision rights that can be delegated. This implies an inverse relationship between contractual completeness and monitoring costs. While several TCE papers examine the determinants of completeness (Crocker and Masten, 1991; Crocker and Reynolds, 1993; Saussier, 2000), they generally focus on asset specificity, not monitoring costs, as the independent variable.

Organizational learning. Our approach also has implications for organizational learning. If entrepreneurship, and hence economic organization, is the act of arranging heterogeneous capital resources, then it is important to understand how individuals and teams learn to do this successfully. Mayer and Argyres (2004) show that contracting parties do not necessarily anticipate contractual hazards, and design arrangements to mitigate them, as TCE predicts; rather, contracting parties must often experience maladaptation to adjust to it. It is thus important to understand not only efficient contracting, but the process of learning to contract efficiently. In our framework, contracting — an exchange of legal rights and responsibilities governing the exchange of property titles - is part of the process of entrepreneurial experimentation. Just as asset attributes must be created or discovered over time, the efficient contractual arrangements governing asset uses must be created or discovered over time, through experimentation. Conceiving the problem this way calls for a theory of learning to organize heterogeneous capital. 


\section{REFERENCES}

Alchian, Armen A. 1965. "Some Economics of Property Rights," Il Politico, 30, 816-29. Reprinted in Alchian (1977), Economic Forces at Work. Indianapolis, IN: Liberty Press.

Alchian, Armen A. and Harold Demsetz. 1972. "Production, Information Costs, and Economic Organization," American Economic Review 62: 777-94.

Alvarez, Sharon, and Jay Barney. 2005. "Discovery and Creation: Alternative Theories of Entrepreneurial Action," Working Paper, Department of Management and Human Resources, Fisher College of Business, Ohio State University.

Barney, Jay. 1991. "Firm Resources and Sustained Competitive Advantage," Journal of Management 17(1): 99-120.

Barzel, Yoram. 1997. Economic Analysis of Property Rights. Cambridge: Cambridge University Press.

Black, J.A. and K.E. Boal. 1994. "Strategic Resources: Traits, Configurations and Paths to Sustainable Competitive Advantage," Strategic Management Journal 15: 131-48.

Böhm-Bawerk, Eugen von. 1889. Positive Theory of Capital. North-Holland, Ill.: Libertarian Press, 1959.

Böhm-Bawerk, Eugen von. 1959. Capital and Interest. South-Holland: Libertarian Press

Casson, Mark C. 1982. The Entrepreneur: An Economic Theory. Oxford: Martin Robertson, 2nd. ed. Edward Elgar, 1999.

Chandler, Alfred D. 1990. Strategy and Structure:Chapters in the History of the Industrial Enterprise. MIT Press.

Chiles, T. H. 2003. "Process Theorizing: Too Important to Ignore in a Kaleidic World." Academy of Management Learning \& Education 2(3): 288-91.

Chiles, T. H. and T.Y. Choi. 2000. "Theorizing TQM: An Austrian and Evolutionary Economics Interpretation." Journal of Management Studies 37(2): 185-212.

Clark, J. B. 1893. "The Genesis of Capital," Yale Review 2: 302-15.

Coase, Ronald H. 1960. "The Problem of Social Cost," Journal of Law and Economics 3(1): 144.

Crocker, Keith J., and Scott E. Masten. 1991. "Pretia Ex Machina? Prices and Process in LongTerm Contracts." Journal of Law and Economics 34: 69-99.

Crocker, Keith J., and Kenneth J. Reynolds. 1993. "The Efficiency of Incomplete Contracts: An Empirical Analysis of Air Force Engine Procurement." Rand Journal of Economics 36: 12646.

Debreu. 1959. Theory of Value. New York: Wiley.

Demsetz, Harold. 1964. "The Exchange and Enforcement of Property Rights," Journal of Law and Economics 7: 11-26.

Demsetz, Harold. 1967. "Toward a Theory of Property Rights," American Economic Review 57(2): 347-59. 
Demsetz, Harold. 1988. "Profit as a Functional Return: Reconsidering Knight's Views," in idem. 1988. Ownership, Control and the Firm. Oxford and New York: Blackwell.

Demsetz, Harold. 1991. "The Theory of the Firm Revisited," in Oliver E. Williamson and Sidney G. Winter, eds. 1991. The Nature of the Firm, Oxford: Blackwell.

Denrell, Jerker., C. Fang, and Sidney G. Winter. 2003. "The Economics of Strategic Opportunity," Strategic Management Journal 24(10): 977-90.

Dierickx, I., and K. Cool. 1989. "Asset Stock Accumulation and Sustainability of Competitive Advantage, Management Science 35: 1504-11.

Fleming, L. 2001. "Recombinant Uncertainty in Technological Search," Management Science 47: 117-32.

Foss, Kirsten and Nicolai Foss. 2001. "Assets, Attributes and Ownership," (with Kirsten Foss), International Journal of the Economics of Business 8: 19-37.

Foss, Kirsten and Nicolai Foss. 2005. "Transaction Costs and Value: How Property Rights Economics Furthers the Resource-based View," Strategic Management Journal (forthcoming).

Foss, Kirsten, Nicolai Foss, Peter G. Klein and Sandra Klein. 2007. "The Entrepreneurial Organization of Heterogeneous Capital,” Journal of Management Studies 44: 1165-86.

Garrison, Roger W. 2000. Time and Money: The Macroeconomics of Capital Structure. London: Routledge.

Gartner, William B. 1990. "What are we talking about when we talk about Entrepreneurship?" Journal of Business Venturing 5(1): 15-28.

Grant, R.M. 1996. "Toward a Knowledge-Based Theory of the Firm." Strategic Management Journal 17: 109-22.

Grossman, Sanford J. and Oliver D. Hart. 1986. "The Costs and Benefits of Ownership: A Theory of Vertical and Lateral Integration,” Journal of Political Economy 94: 691-719.

Hamilton, James D. 1990. "Analysis of Time Series Subject to Changes in Regime," Journal of Econometrics 45(1-2): 39-70.

Harper, David. 1996. Entrepreneurship and the Market Process. London: Routledge.

Hart, Oliver and John Moore. 1990. "Property Rights and the Nature of the Firm," Journal of Political Economy 98 (6): 1119-58.

Hart, Oliver. 1995. Firms, Contracts and Financial Structure. Oxford: Clarendon Press.

Hayek, F.A. 1928. "Intertemporal Price Equilibrium and Movements in the Value of Money," in

Hayek, F. A. 1931. Prices and Production. London: Routledge \& Sons.

Hayek, F. A. 1935. Collectivist Economic Planning. London: Rouledge and Kegan Paul.

Hayek, F. A. 1941. The Pure Theory of Capital. Chicago: University of Chicago Press.

Hayek, F. A. 1948. Individualism and Economic Order. Chicago: University of Chicago Press.

Hayek, F. A. 1968. "Competition as a Discovery Procedure.” Translated by Marcellus S. Snow. Quarterly Journal of Austrian Economics 5: 9-23. 
Henderson, Rebecca M., and Kim B. Clark. 1990. "Architectural Innovation: The Reconfiguration of Existing Product Technologies and the Failure of Established Firms," Administrative Science Quarterly 35(1): 9-30.

Hill, Charles W. L., and David L. Deeds. 1996. "The Importance of Industry Structure for the Determination of Firm Profitability: A Neo-Austrian Perspective," Journal of Management Studies 33: 429-51.

Jacobson, Robert. 1992. "The 'Austrian' School of Strategy," Academy of Management Review 17: $782-807$.

Jensen, Michael C., and William H. Meckling. 1992. "Specific and General Knowledge, and Organizational Structure," in Lars Werin and Hans Wijkander, eds., Contract Economics. Oxford: Blackwell.

Kauffman, Stuart A. 1993. The Origins of Order: Self-Organization and Section in Evolution. New York: Oxford University Press.

Kim, Jongwook, and Joseph T. Mahoney. 2002. "Resource-Based and Property Rights Perspectives on Value Creation: The Case of Oil Field Unitization." Managerial and Decision Economics 23(4): 225-45.

Kim, Jongwook, and Joseph T. Mahoney. 2005. "Property Rights Theory, Transaction Costs Theory, and Agency Theory: An Organizational Economics Approach to Strategic Management." Managerial and Decision Economics 26(4): 223-42.

Kirzner, Israel M. 1966. An Essay on Capital. New York: Augustus M. Kelley.

Kirzner, Israel M. 1973. Competition and Entrepreneurship. Chicago: University of Chicago Press.

Kirzner, Israel M. 1996. "Reflections on the Misesian Legacy in Economics," The Review of Austrian Economics 9(2): 143-154.

Knight, Frank H. 1921. Risk, Uncertainty, and Profit. New York: August M. Kelley.

Lachmann, Ludwig M. 1947. "Complementarity and Substitution in the Theory of Capital," Economica 14(54): 108-119.

Lachmann, Ludwig M. 1956. Capital and Its Structure. Kansas City: Sheed Andrews and McMeel, 1978.

Lachmann, Ludwig M. 1976. "From Mises to Shackle:An Essay on Austrian Economics and the Kaleidic Society,“ Journal of Economic Literature 14(1): 54-62.

Lachmann, Ludwig M. 1977. Capital, Expectations, and the Market Process. Kansas City: Sheed Andrews and McMeel.

Lachmann, Ludwig M. 1986. The Market as a Process. Oxford: Basil Blackwell.

Langlois, Richard N. 1992. "Transaction Cost Economics in Real Time," Industrial and Corporate Change 1(1): 99-127.

Langlois, Richard N. 2001. "Strategy and the Market Process: Introduction to the Special Issue." Managerial and Decision Economics 22: 163-68.

Langlois, Richard N. 2002. "Modularity in Technology and Organization," Journal of Economic Behavior and Organization 49(1): 19-37. 
Langlois, Richard N. 2003. "The Vanishing Hand: The Changing Dynamics of Industrial Capitalism," Industrial and Corporate Changes 12(2): 351-85.

Langlois, Richard N. and Nicolai J. Foss. 1999. "Capabilities and Governance: the Rebirth of Production in the Theory of Economic Organization," KYKLOS 52: 201-18.

Levinthal, Daniel. 1997. “Adaptation on Rugged Landscapes," Management Science 43: 934-50.

Lewin, Peter. 1999. Capital in Disequilibrium: The Role of Capital in a Changing World. New York and London: Routledge.

Lewin, Peter. 2005. "The Firm in Disequilibrium: Contributions from the Austrian Tradition," Working Paper, University of Texas at Dallas.

Lippman, Steven A. and Richard P. Rumelt. 1982.'Uncertain Imitability: An Analysis of Interfirm Differences in Efficiency under Competition," The Bell Journal of Economics 13(2): 418-438.

Lippman, S. A. and Rumelt, Richard P. 2003. "A Bargaining Perspective on Resource Advantage," Strategic Management Journal 24: 1069-86.

Loasby Brian J. 1976. Choice, Complexity and Ignorance: An Inquiry into Economic Theory and the Practice of Decision Making. Cambridge: Cambridge University Press.

Mahoney, Joseph M. 1995. "The Management of Resources and the Resource of Management," Journal of Business Research 33: 91-101.

Mayer, Kyle J., and Nicholas S. Argyres. 2004. "Learning to Contract: Evidence from the Personal Computer Industry," Organization Science 15(4): 394-410.

Menger, Carl. 1871. Principles of Economics. New York: New York University Press, 1985.

Mises, Ludwig von. 1920. "Economic Calculation in the Socialist Commonwealth." In F. A. Hayek, ed., Collectivist Economic Planning. London: Routledge \& Sons, 1935.

Mises, Ludwig von. 1949. Human Action. New Haven: Yale University Press.

Nickerson, Jackson and Zenger, Todd. 2004. "A Knowledge-based Theory of the Firm: The Problem-Solving Perspective," Organization Science 15(6): 617-32.

Penrose, Edith T. 1959. The Theory of the Growth of the Firm. Oxford: Blackwell.

Ricketts, Martin. 1987. The New Industrial Economics: An Introduction to Modern Theories of the Firm. New York: St. Martin's Press.

Rivkin, Jan W. 2000. "Imitation of Complex Strategies," Management Science 46(6): 824-844.

Roberts, Peter W., and K. M. Eisenhardt. 2003. "Austrian Insights on Strategic Organization: From Market Insights to Implications for Firms." Strategic Organization 1: 345-52.

Rothbard, Murray N. 1962. Man, Economy, and State: A Treatise on Economic Principles. Princeton, N.J.: Van Nostrand.Salerno. 1999.

Saussier, Stéphane. 2000. "Transaction Costs and Contractual Incompleteness: The Case of Electricitie de France," Journal of Economic Behavior and Organization 42: 189-206.

Schultz, Theodore W. 1975. "The Value of the Ability to Deal with Disequilibria," Journal of Economic Literature 13: 827-46. 
Schumpeter, Joseph A. 1934. The Theory of Economic Development: An Inquiry into Profits, Capital, Credit, Interest, and the Business Cycle. Translated by Redvers Opie. Cambridge, Mass., Harvard University Press.

Schumpeter, Joseph A. 1954. History of Economic Analysis. Cambridge, Mass.: Harvard University Press.

Shane, S. 2000. "Prior Knowledge and the Discovery of Entrepreneurial Opportunities," Organization Science 11: 448-469.

Shane, S. 2003. A General Theory of Entrepreneurship. Cheltenham: Edward Elgar.

Simon, Herbert A. 1955. "A Behavioral Model of Rational Choice," Quarterly Journal of Economics 69: 99-118.

Simon, Herbert A. 1962. "The Architecture of Complexity," Proceedings of the American Philosophical Society 106: 467-82.

Solow, Robert. 1957. "Technical Change and the Aggregate Production Function," Review of Economics and Statistics 39: 312-20.

Strigl, Richard von. 1934. Capital and Production. Auburn, Ala.: Ludwig von Mises Institute, 2000.

Teece, David J. 1982. "Toward an Economic Theory of the Multiproduct Firm," Journal of Economic Behavior and Organization 3: 39-63.

Wernerfelt, Birger. 1984. “A Resource-Based View of the Firm," Strategic Management Journal 5: $272-80$.

Williamson, Oliver E. 1975. Markets and Hierarchies: Analysis and Antitrust Implications. New York: Free Press.

Williamson, Oliver E. 1985. The Economic Institutions of Governance. New York: Free Press.

Williamson, Oliver E. 1991. "Comparative Economic Organization: The Analysis of Discrete Structural Alternatives," Administrative Science Quarterly 36: 269-96.

Williamson, Oliver E. 1996. The Mechanisms of Governance. Oxford: Oxford University Press.

Winter, Sidney G. 1988. "On Coase, Competence, and the Corporation," Journal of Law, Economics, and Organization 4(1): 163-80. 


\section{SMG - Working Papers \\ www.cbs.dk/smg \\ 2003}

2003-1: Nicolai J. Foss, Kenneth Husted, Snejina Michailova, and Torben Pedersen: Governing Knowledge Processes: Theoretical Foundations and Research Opportunities.

2003-2: Yves Doz, Nicolai J. Foss, Stefanie Lenway, Marjorie Lyles, Silvia Massini, Thomas P. Murtha and Torben Pedersen: Future Frontiers in International Management Research: Innovation, Knowledge Creation, and Change in Multinational Companies.

2003-3: Snejina Michailova and Kate Hutchings: The Impact of In-Groups and OutGroups on Knowledge Sharing in Russia and China CKG Working Paper.

2003-4: Nicolai J. Foss and Torben Pedersen : The MNC as a Knowledge Structure: The Roles of Knowledge Sources and Organizational Instruments in MNC Knowledge Management CKG Working Paper.

2003-5: Kirsten Foss, Nicolai J. Foss and Xosé H. Vázquez-Vicente: “Tying the Manager's Hands": How Firms Can Make Credible Commitments That Make Opportunistic Managerial Intervention Less Likely CKG Working Paper.

2003-6: Marjorie Lyles, Torben Pedersen and Bent Petersen: Knowledge Gaps: The Case of Knowledge about Foreign Entry.

2003-7: Kirsten Foss and Nicolai J. Foss: The Limits to Designed Orders: Authority under "Distributed Knowledge" CKG Working Paper.

2003-8: Jens Gammelgaard and Torben Pedersen: Internal versus External Knowledge Sourcing of Subsidiaries - An Organizational Trade-Off.

2003-9: Kate Hutchings and Snejina Michailova: Facilitating Knowledge Sharing in Russian and Chinese Subsidiaries: The Importance of Groups and Personal Networks Accepted for publication in Journal of Knowledge Management.

2003-10: Volker Mahnke, Torben Pedersen and Markus Verzin: The Impact of Knowledge Management on MNC Subsidiary Performance: the Role of Absorptive Capacity CKG Working Paper.

2003-11: Tomas Hellström and Kenneth Husted: Mapping Knowledge and Intellectual Capital in Academic Environments: A Focus Group Study Accepted for publication in Journal of Intellectual Capital CKG Working Paper.

2003-12: Nicolai J Foss: Cognition and Motivation in the Theory of the Firm: Interaction or "Never the Twain Shall Meet"? Accepted for publication in Journal des Economistes et des Etudes Humaines CKG Working Paper.

2003-13: Dana Minbaeva and Snejina Michailova: Knowledge Transfer and Expatriation Practices in MNCs: The Role of Disseminative Capacity.

2003-14: Christian Vintergaard and Kenneth Husted: Enhancing Selective Capacity Through Venture Bases. 


\section{4}

2004-1: Nicolai J. Foss: Knowledge and Organization in the Theory of the Multinational Corporation: Some Foundational Issues

2004-2: Dana B. Minbaeva: HRM Practices and MNC Knowledge Transfer

2004-3: Bo Bernhard Nielsen and Snejina Michailova: Toward a Phase-Model of Global Knowledge Management Systems in Multinational Corporations

2004-4: Kirsten Foss \& Nicolai J Foss: The Next Step in the Evolution of the RBV: Integration with Transaction Cost Economics

2004-5: Teppo Felin \& Nicolai J. Foss: Methodological Individualism and the Organizational Capabilities Approach

2004-6: Jens Gammelgaard, Kenneth Husted, Snejina Michailova: Knowledge-sharing Behavior and Post-acquisition Integration Failure

2004-7: Jens Gammelgaard: Multinational Exploration of Acquired R\&D Activities

2004-8: Christoph Dörrenbächer \& Jens Gammelgaard: Subsidiary Upgrading? Strategic Inertia in the Development of German-owned Subsidiaries in Hungary

2004-9: Kirsten Foss \& Nicolai J. Foss: Resources and Transaction Costs: How the Economics of Property Rights Furthers the Resource-based View

2004-10: Jens Gammelgaard \& Thomas Ritter: The Knowledge Retrieval Matrix: Codification and Personification as Separate Strategies

2004-11: Nicolai J. Foss \& Peter G. Klein: Entrepreneurship and the Economic Theory of the Firm: Any Gains from Trade?

2004-12: Akshey Gupta \& Snejina Michailova: Knowledge Sharing in Knowledge-Intensive Firms: Opportunities and Limitations of Knowledge Codification

2004-13: Snejina Michailova \& Kate Hutchings: Knowledge Sharing and National Culture: A Comparison Between China and Russia

\section{5}

2005-1: Keld Laursen \& Ammon Salter: My Precious - The Role of Appropriability Strategies in Shaping Innovative Performance

2005-2: Nicolai J. Foss \& Peter G. Klein: The Theory of the Firm and Its Critics: A Stocktaking and Assessment

2005-3: Lars Bo Jeppesen \& Lars Frederiksen: Why Firm-Established User Communities Work for Innovation: The Personal Attributes of Innovative Users in the Case of Computer-Controlled Music

2005-4: Dana B. Minbaeva: Negative Impact of HRM Complementarity on Knowledge Transfer in MNCs

2005-5: Kirsten Foss, Nicolai J. Foss, Peter G. Klein \& Sandra K. Klein: Austrian Capital 
Theory and the Link Between Entrepreneurship and the Theory of the Firm

2005-1: Nicolai J. Foss: The Knowledge Governance Approach

2005-2: Torben J. Andersen: Capital Structure, Environmental Dynamism, Innovation Strategy, and Strategic Risk Management

2005-3: Torben J. Andersen: A Strategic Risk Management Framework for Multinational Enterprise

2005-4: Peter Holdt Christensen: Facilitating Knowledge Sharing: A Conceptual Framework

2005-5 Kirsten Foss \& Nicolai J. Foss: Hands Off! How Organizational Design Can Make Delegation Credible

2005-6 Marjorie A. Lyles, Torben Pedersen \& Bent Petersen: Closing the Knowledge Gap in Foreign Markets - A Learning Perspective

2005-7 Christian Geisler Asmussen, Torben Pedersen \& Bent Petersen: How do we Capture "Global Specialization" when Measuring Firms' Degree of internationalization?

2005-8 Kirsten Foss \& Nicolai J. Foss: Simon on Problem-Solving: Implications for New Organizational Forms

2005-9 Birgitte Grøgaard, Carmine Gioia \& Gabriel R.G. Benito: An Empirical Investigation of the Role of Industry Factors in the Internationalization Patterns of Firms

2005-10 Torben J. Andersen: The Performance and Risk Management Implications of Multinationality: An Industry Perspective

2005-11 Nicolai J. Foss: The Scientific Progress in Strategic Management: The case of the Resource-based view

2005-12 Koen H. Heimeriks: Alliance Capability as a Mediator Between Experience and Alliance Performance: An Empirical Investigation Into the Alliance Capability Development Process

2005-13 Koen H. Heimeriks, Geert Duysters \& Wim Vanhaverbeke: Developing Alliance Capabilities: An Empirical Study

2005-14 JC Spender: Management, Rational or Creative? A Knowledge-Based Discussion

\section{6}

2006-1: Nicolai J. Foss \& Peter G. Klein: The Emergence of the Modern Theory of the Firm

2006-2: Teppo Felin \& Nicolai J. Foss: Individuals and Organizations: Thoughts on a Micro-Foundations Project for Strategic Management and Organizational Analysis

2006-3: Volker Mahnke, Torben Pedersen \& Markus Venzin: Does Knowledge Sharing 
Pay? An MNC Subsidiary Perspective on Knowledge Outflows

2006-4: Torben Pedersen: Determining Factors of Subsidiary Development

2006-5 Ibuki Ishikawa: The Source of Competitive Advantage and Entrepreneurial Judgment in the RBV: Insights from the Austrian School Perspective

2006-6 Nicolai J. Foss \& Ibuki Ishikawa: Towards a Dynamic Resource-Based View: Insights from Austrian Capital and Entrepreneurship Theory

2006-7 Kirsten Foss \& Nicolai J. Foss: Entrepreneurship, Transaction Costs, and Resource Attributes

2006-8 Kirsten Foss, Nicolai J. Foss \& Peter G. Klein: Original and Derived Judgement: An Entrepreneurial Theory of Economic Organization

2006-9 Mia Reinholt: No More Polarization, Please! Towards a More Nuanced Perspective on Motivation in Organizations

2006-10 Angelika Lindstrand, Sara Melen \& Emilia Rovira: Turning social capital into business? A study of Swedish biotech firms' international expansion

2006-11 Christian Geisler Asmussen, Torben Pedersen \& Charles Dhanaraj: Evolution of Subsidiary Competences: Extending the Diamond Network Model

2006-12 John Holt, William R. Purcell, Sidney J. Gray \& Torben Pedersen: Decision Factors Influencing MNEs Regional Headquarters Location Selection Strategies

2006-13 Peter Maskell, Torben Pedersen, Bent Petersen \& Jens Dick-Nielsen: Learning Paths to Offshore Outsourcing - From Cost Reduction to Knowledge Seeking

2006-14 Christian Geisler Asmussen: Local, Regional or Global? Quantifying MNC Geographic Scope

2006-15 Christian Bjørnskov \& Nicolai J. Foss: Economic Freedom and Entrepreneurial Activity: Some Cross-Country Evidence

2006-16 Nicolai J. Foss \& Giampaolo Garzarelli: Institutions as Knowledge Capital: Ludwig M. Lachmann's Interpretative Institutionalism

2006-17 Koen H. Heimriks \& Jeffrey J. Reuer: How to Build Alliance Capabilities

2006-18 Nicolai J. Foss, Peter G. Klein, Yasemin Y. Kor \& Joseph T. Mahoney: Entrepreneurship, Subjectivism, and the Resource - Based View: Towards a New Synthesis

2006-19 Steven Globerman \& Bo B. Nielsen: Equity Versus Non-Equity International Strategic Alliances: The Role of Host Country Governance

\section{7}

2007-1 Peter Abell, Teppo Felin \& Nicolai J. Foss: Building Micro-Foundations for the Routines, Capabilities, and Performance Links 
2007-2 Michael W. Hansen, Torben Pedersen \& Bent Petersen: MNC Strategies and Linkage Effects in Developing Countries

2007-3 Niron Hashai, Christian G. Asmussen, Gabriel R.G. Benito \& Bent Petersen: Predicting the Diversity of Foreign Entry Modes

2007-4 Peter D. Ørberg Jensen \& Torben Pedersen: Whether and What to Offshore?

2007-5 Ram Mudambi \& Torben Pedersen: Agency Theory and Resource Dependency Theory: Complementary Explanations for Subsidiary Power in Multinational Corporations

2007-6 Nicolai J. Foss: Strategic Belief Management

2007-7 Nicolai J. Foss: Theory of Science Perspectives on Strategic Management Research: Debates and a Novel View

2007-8 Dana B. Minbaeva: HRM Practices and Knowledge Transfer in MNCs

2007-9 Nicolai J. Foss: Knowledge Governance in a Dynamic Global Context: The Center for Strategic Management and Globalization at the Copenhagen Business School

2007-10 Paola Gritti \& Nicolai J. Foss: Customer Satisfaction and Competencies: An Econometric Study of an Italian Bank

2007-11 Nicolai J. Foss \& Peter G. Klein: Organizational Governance

2007-12 Torben Juul Andersen \& Bo Berhard Nielsen: The Effective Ambidextrous Organization: A Model of Integrative Strategy Making Processes.

\section{8}

2008-1 Kirsten Foss \& Nicolai J. Foss: Managerial Authority When Knowledge is Distributed: A Knowledge Governance Perspective

2008-2 Nicolai J. Foss: Human Capital and Transaction Cost Economics.

2008-3 Nicolai J. Foss \& Peter G. Klein: Entrepreneurship and Heterogeneous Capital. 